\title{
Early effects of vasectomy on the protein composition of fluid from the rete testis and epididymis of the rat
}

\author{
A. I. Koskimies and ${ }^{*} \mathrm{~K}$. Reijonen \\ $I$ Department of Obstetrics and Gynecology and *Department of Anatomy, \\ University of Helsinki, Helsinki, Finland
}

It is commonly believed that vasectomy does not cause major changes in testicular morphology in the rat (Smith, 1962; Segal, 1972; Plaut, 1973; Neaves, 1974). Some long-term studies, however, have shown that vasectomy has led to the decline of testicular weight and endocrine function (Sackler, Weltman, Pandhi \& Schwartz, 1973; Kinson \& Layberry, 1975). Because the germinal epithelium and sperm production in most animals seem to be intact, the epididymis must adapt to accommodate an increasing number of spermatozoa. Dilatation of the cauda epididymidis and the formation of sperm cysts and sperm granulomata have been reported (Smith, 1962; McGlynn \& Erpino, 1974), but little is known about the effects of vasectomy on epididymal physiology. Jones (1974) suggested that vasectomy does not seriously impair the functional capacity of the cauda epididymidis. The present study was therefore carried out to examine early changes in the proteins of rete testis fluid (RTF) and epididymal fluid after vasectomy.

Twenty-eight mature, male Sprague-Dawley rats were separated into two groups. The animals were anaesthetized with sodium pentobarbitone (Nembutal: Abbott) given intraperitoneally. Surgery was performed under sterile conditions. Vasectomy was effected through a small midline abdominal incision in one group and by a scrotal approach in the other. The left vas deferens was ligated at two points, about $1 \mathrm{~cm}$ apart and about $3 \mathrm{~cm}$ distal to the cauda epididymidis, and severed. The right side served as control. The retention of the testes in the scrotum was checked daily.

Epididymal fluid from the caudal region and from sperm cysts was collected from 4 animals in each group by a micropuncture technique (Tuck, Setchell, Waites \& Young, 1970) 2, 4 and 10 days after operation. To collect RTF from the vasectomized animals the efferent ducts were ligated bilaterally $24 \mathrm{hr}$ before puncturing the dilated rete testis. Epididymal fluid was not obtained from these animals. The samples were subjected to a high-resolution step-gradient acrylamide gel electrophoresis as described by Koskimies \& Kormano (1973).

Five heavily staining prealbumin bands are typically found in rat epididymal fluid after electrophoresis. Two of these bands are not found in RTF or serum (Koskimies \& Kormano, 1975). No changes were found in the protein patterns of epididymal fluid 2 days after vasectomy, but by 4 and 10 days there was increased staining of the prealbumin bands (Text-fig. 1). The RTF from the vasectomized side was similar to that obtained from the control side. The fluid in the sperm cysts was contaminated with serum proteins by 2 days after vasectomy, and by 4 days the pattern was similar to that of serum but the specific epididymal bands were also present, although weak (Textfig. 1). There were no differences in the protein patterns related to the operative approach.

Histological examination of the testes and epididymides showed that there were some differences in the two groups. By 2 days after vasectomy via the scrotum, the seminiferous tubules contained accumulations of spermiogenic cells, but the epithelium looked normal. There was little further change and by 10 days there were hardly any spermatozoa in the caput epididymidis. In the cauda region the tubules were packed with spermatozoa and by 2 days after vasectomy 1 or 2 sperm cysts were present. The epithelium of these cysts seemed discontinuous in places (see also Smith, 1962). By 10 days, some of the sperm cysts showed organization into granulomata. In the animals vasectomized via the abdomen, multinucleated cells were seen in some seminiferous tubules 2 and 4 days after operation. The cells resembled the multinucleated degenerating spermatids seen after artificial cryptorchidism (Niemi \& Kormano, 1965), and represent a nonspecific reaction to injury (Smith, 1962). The caput epididymidis was filled with degenerating cells which were probably of the 


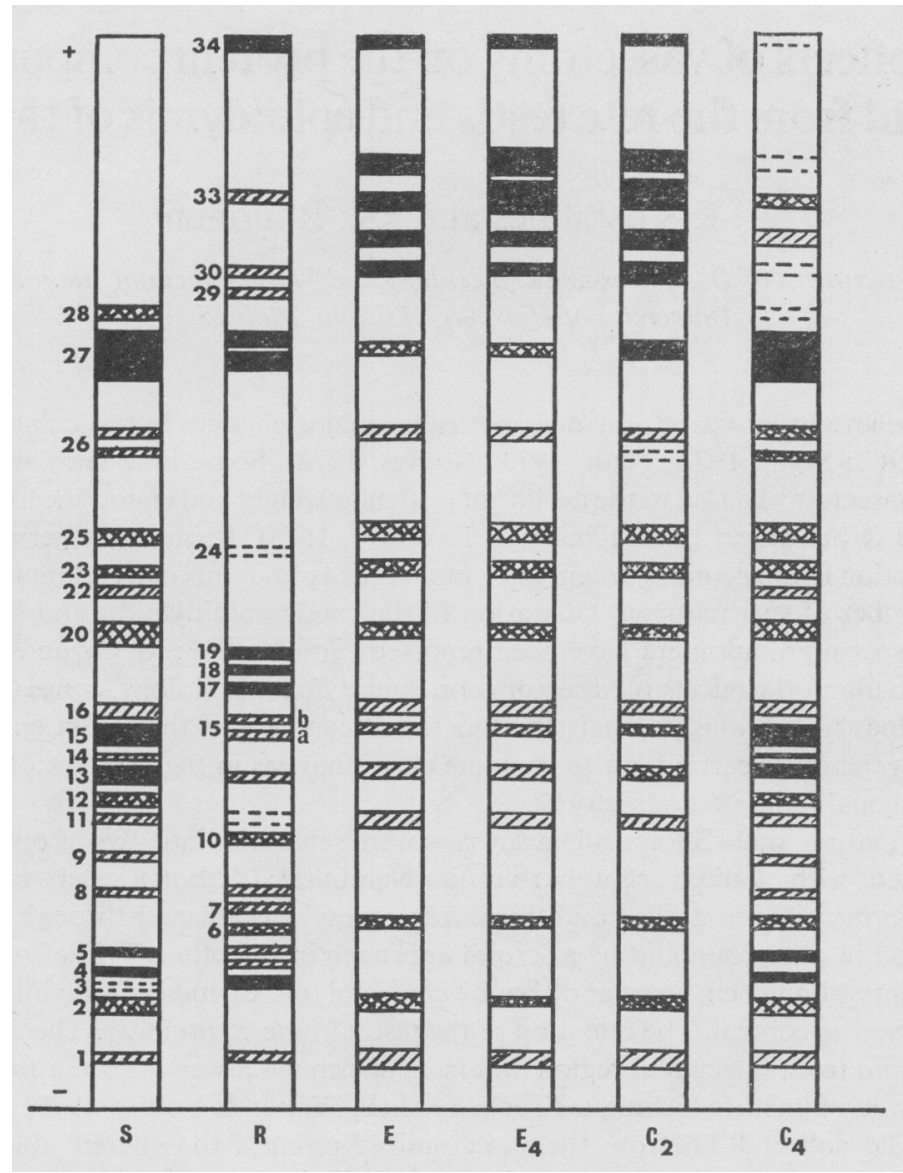

Text-fig. 1. Diagram showing the protein bands separated with step-gradient acrylamide gel electrophoresis. $S=$ serum; $R=$ rete testis fluid; $E=$ epididymal fluid; $E_{4}=$ epididymal fluid 4 days after vasectomy; $C_{2}$ and $C_{4}=$ sperm cyst fluids 2 and 4 days after vasectomy.

same origin. By 10 days there were fewer multinucleated cells in the testis and the tubules of the caput epididymidis were nearly empty.

The increased staining of the prealbumin bands of epididymal fluid shows that these proteins are concentrated in the duct. This may be due to undisturbed secretion of the proteins or their decreased reabsorption. The protein pattern of the RTF was distinct, even 10 days after vasectomy, and there was no contamination with epididymal fluid. The appearance of exfoliated cells from the germinal epithelium in the proximal parts of the epididymis also indicates the direction of flow of fluid, and thus the possibility of backflow of epididymal fluid is excluded. These differences in testicular morphology between the two operative groups must be considered a secondary effect unrelated to vasectomy but caused by the more traumatic abdominal approach as shown by Heller \& Rothchild (1974).

Vasectomy is known to induce spermagglutinins in man and other animals (Phadke, 1964; Rümke \& Titus, 1970; Ansbacher, 1971), but it is not known how and where sperm antigens pass from the excurrent duct system. The fact that seminal fluid in sperm cysts is contaminated with serum shows that the epithelium can no longer act as a barrier, and it seems possible that the cysts could be the site of the leakage of sperm antigens. 


\section{References}

ANSBACHER, R. (1971) Sperm-agglutinating and spermimmobilizing antibodies in vasectomized men. Fert. Steril. 22, 629-632.

Heller, G.V. \& RothCHILD, I. (1974) The influence of the surgical technique used for vasectomy on testis function in rats. $\mathcal{J}$. Reprod. Fert. 39, 81-84.

JONEs, R. (1974) Epididymal function in the vasectomized rabbit. J. Reprod. Fert. 36, 199-202.

Kinson, G.A. \& LAYberRy, R.A. (1975) Long-term endocrine response to vasectomy in the adult rat. Contraception 11, 143-150.

Koskimies, A.I. \& KoRmano, M. (1973) The proteins in fluids from the seminiferous tubules and rete testis of the rat. J. Reprod. Fert. 34, 433-444.

Koskimies, A.I. \& Kormano, M. (1975) Proteins in fluids from different segments of the rat epididymis. J. Reprod. Fert. 43, 345-348.

McGlynn, J.M. \& ERpino, M.J. (1974) Effects of vasectomy on the reproductive system and sexual behaviour of rats. J. Reprod. Fert. 40, 241-247.

Neaves, W.B. (1974) The rat testis after vasectomy. J. Reprod. Fert. 40, 39-44.

Niemi, M. \& Kormano, M. (1965) Response of the cycle of the seminiferous epithelium of the rat testis to artificial cryptorchidism. Fert. Steril. 16, 235-242.

PhadKe, A.M. (1964) Fate of spermatozoa in cases of obstructive azoospermia and after ligation of vas deferens in man. J. Reprod. Fert. 7, 1-12.

Plaut, S.M. (1973) Testicular morphology in rats vasectomized as adults. Science, N.Y. 179, 554-555.

RüMkE, P. \& TITus, M. (1970) Spermagglutinin formation in male rats by subcutaneously injected syngeneic epididymal spermatozoa and by vasoligation and vasectomy. J. Reprod. Fert. 21, 69-79.

Sackler, A.M., Weltman, A.S., Pandhi, V. \& SchWARTZ, R. (1973) Gonadal effects of vasectomy and vasoligation. Science, N.Y. 179, 293-295.

SEGAL, R.J. (1972) Effect of vasoligation of 14-day-old and 21-day-old rats on spermatogenesis. Int. J. Fert. 17, 33-34.

Smith, G. (1962) The effects of ligation of the vasa efferentia and vasectomy on testicular function in the aduit rat. $J$. Endocr. 23, 385-399.

TuCK, R.R., Setchell, B.P., Waites, G.M.H. \& Young, J.A. (1970) The composition of fluid collected by micropuncture and catheterization from the seminiferous tubules and rete testis of rats. Pfügers Arch. ges. Physiol. 318, 225-243.

Received 12 November 1975 